\title{
Prioritization of occupational health and safety indicators using the Fuzzy-AHP method
}

\author{
Guilherme Neto Ferraria (D), Gislaine Camila Lapasini Leal $^{\text {** }}$ (D), Edwin Vladimir Cardoza Galdamez ${ }^{\mathrm{a}}$ (D), \\ Rodrigo Clemente Thom de Souza ${ }^{b}$ \\ aPrograma de Pós-Graduação em Engenharia de Produção, Universidade Estadual de Maringá, Maringá, PR, Brasil \\ bUniversidade Federal do Paraná, Jandaia do Sul, PR, Brasil \\ *gclleal@uem.br
}

\begin{abstract}
Paper aims: This paper aims to assist and facilitate decision-making in health management and work safety by the identification and prioritization of occupational health and safety indicators.

Originality: This research contributes to the literature by demonstrating the applicability of multicriteria tools to solve health and safety-related issues on organizations and also some implications related to this method.

Research method: The methodological approach is the application of the Fuzzy AHP method for prioritization of categories of occupational health and safety indicators.

Main findings: The results show that the category of indicators called "Occupational Health and Safety Management" was considered the most relevant, followed by the categories "Accidents and Diseases" and "Risk Assessment".

Implications for theory and practice: For the application of the Fuzzy AHP method it is necessary to compare the level of importance between objects. Collecting these assessments can be difficult. In this paper, more than forty companies were reached but only six responded and only two responses were valid.
\end{abstract}

\section{Keywords}

Work safety. Multicriteria method. OHS management.

How to cite this article: Ferrari, G. N., Leal, G. C. L., Galdamez, E. V. C., \& Souza, R. C. T. (2020). Prioritization of occupational health and safety indicators using the fuzzy-ahp method. Production, 30, e20200054. https://doi. $\operatorname{org} / 10.1590 / 0103-6513.20200054$

Received: May 29, 2020; Accepted: Sep. 22, 2020.

\section{Introduction}

Representing financial costs and productivity penalties, work accidents and occupational diseases generate concerns in organizations in a global sphere. Although strategies to reduce or eliminate occupational risks and measures of prevention are being increasingly developed worldwide, accidents remain very frequent (Alli, 2008).

According to the Yearbook of Social Security Statistical, in 2018 approximately 235 thousand accidental benefits were granted, including pension for death, sickness, and accident assistance, representing a cost of $\mathrm{R} \$$ 366,723.00 (Brasil, 2018). Also, between 2012 and 2018, a total of 351,796,758 working days were lost due to work leave, this number takes into account every work leave that happened across the country even if it happened simultaneously, according to the Digital Observatory on Occupational Health and Safety (2018).

International standards, such as ISO 45000, offer guidelines for the standardization of the organization's Occupational Health and Safety Management System (OHSMS), defining criteria, policies and objectives to be followed, however, for these safety measures to be effective, companies need to maintain control over them (Almeida \& Nunes, 2014; International Organization for Standardization, 2018). 
One way to avoid accidents and maintain control over the achievement of objectives and goals is through the development and use of indicators (Øien et al., 2011a). The Occupational Health and Safety (OHS) indicators evaluate safety measures and diagnose what is out of legal compliance, providing fundamental information for the planning of accident protection and prevention measures (Almeida \& Nunes, 2014).

However, it's necessary that the set of OHS indicators used by the organization is the most appropriate for the company's reality and that its data collection is substantial for the improvement of the organization's security management since the incorrect use of indicators means a waste of time and resources for the manager, as well as represents a poor safety culture (Oswald, 2020).

The choice of the most suitable indicators is difficult due to the multiple layers of variables and the different meanings that the same indicator may have depending on the context (Barbosa et al., 2019). Therefore, it is possible to apply methods to support decision-making in a way that helps to identify the most appropriate and priority indicators for the company's situation (Kongsvik et al. 2010). According to Hora \& Costa (2015), there are several methods of decision-making support, the choice of the best method depends on what is the problem that needs to be solved.

In situations in which decision-making is influenced by conflicting factors, it's possible to apply the so-called multicriteria methods, which consider several aspects to reach an option considered the best (Briozo \& Musetti, 2015). Methods like AHP has been one of the most applied in prioritization and selection of indicators because it helps to achieve a better alternative considering the presence of several variables and difficulties, however, this process can be biased due to human subjectivity and ambiguity (Govindan et al., 2017). To consider the uncertainties and to handle the human perceptions efficiently, fuzzy concepts can be combined to the decisionmaking method, like the Fuzzy Analytic Process (FAHP) that uses an assessment scale based on linguistic terms to make possible the inclusion of subjective information making the evaluation process closer to reality (Govindan et al., 2017; Cobo et al., 2014). When it comes to the selection of indicators related to Occupational Health and Safety, the FAHP can also be applied successfully (Janackovic et al., 2013).

This study aims to answer the research question: what are the indicators that can be used by companies to assist the management of OHS? However, different organizations may have different opinions about the same indicators, which means that an application of a method capable of evaluating the level of relevance among a set of indicators is needed (Barbosa et al., 2019). Therefore, the objective of this study is to make use of the Fuzzy AHP application as a tool to define the priority rank among a set of indicators. Thus, this paper has three steps: first, the main OHS indicators known in the bibliography are identified, then they are systematized into categories according to similar characteristics, and finally, the FAHP is structured and applied to different companies in order to identify which of these categories is considered the most important.

\section{Literature review}

\subsection{Occupational Health and Safety (OHS)}

According to Alli (2008), OHS is defined as the science that recognizes, evaluates, and controls growing risks located or arising from the work area that can affect the health and well-being of workers. OHS involves factors and conditions that impact the safety, health, and comfort of workers, visitors or anyone else in the work environment (Occupational Health and Safety Assessment Series, 2007).

The dangers that exist in a work environment endanger its workers, the equipment, the structure of the place and the internal environment itself, as well as the external environment that surrounds it, impacting the economic performance of the organization and its competitiveness in the market (Mohammadfam et al., 2017). According to Sadoughi et al. (2012), organizations need to act not only in meeting the needs of their customers but also in guaranteeing the health and safety of their team and the entire work environment, in this context, some of the expectations of stakeholders refer to the comply of requirements in the area of health, safety, and environment.

All companies with workers must carry out regular assessments of the work environment's risks and the its worker's health and to develop prevention programs (Chaves et al., 2009). Programs to control and improve the conditions of the work environment, in addition to help to minimize costs with accidents and occupational diseases also bring social value, valuing the self-esteem and quality of life of workers (Quelhas et al., 2014).

The guarantee of a safe work environment is not only important for the physical integrity of the worker but also guarantees factors such as productivity, quality, and continuity of production (Dağdeviren \& Yüksel, 2008; Zheng et al., 2012; Nordlöf et al., 2017). Vassem et al. (2017) say that accident prevention brings benefits from 
the company's internal and external points of view, the first related to efficiency gains and improvement of the organizational climate and the second related to the company's reputation and cost minimization.

\subsection{OHS Management Systems (OHSMS)}

According to Occupational Health and Safety Assessment Series (2007), an OHSMS is part of a global organizational management system that facilitates the management of the company's risks, including planning activities, information on health responsibilities, as well as processes and resources to be developed, analyzed and maintained to carry out the corporate safety policy. According to Wachter \& Yorio (2014), OHSMS are developed to identify, assess, control, and reduce safety risks, as well as creating defenses to prevent accidents. According to Mohammadfam et al. (2017), OHSMS are powerful tools capable of helping organizations to control and manage risks, improve OHS conditions in the workplace, enable safer and healthier places, and benefit the safety culture.

Everyone within the production process is responsible and must be committed to OHS management activities, managers being responsible for identifying risks and guiding employees, as well as allocating resources for the correct functioning of safety programs, the establishment of functions, and organizational structures to support employers in their OHS functions. They are also responsible for controlling the OHS measures and to set a positive example for their workers. While it is the role of the workers to cooperate with top management, participating in the stages of defining problems and objectives, as well as participating in training and reactive actions (Alli, 2008; Quelhas et al., 2014).

The organization can achieve success in OHS management through the definition of indicators, methods of data collection and analysis, monitoring the performance of the established safety actions, as well as enabling the dissemination of results for the entire company (da Silva et al., 2013; Quelhas et al., 2014).

Besides, 1S0 45001:2018 defines that the organization must carry out measures for monitoring, analyzing and evaluating performance concerning OHS, defining what should be measured, what will be the monitoring methods, when should the measures be taken and when the results should be analyzed, with this, the organization maintains constant data on the internal OHS situation and the effectiveness of its management system (International Organization for Standardization, 2018). According to the International Labor Organization, the introduction of ISO 45001, combined with existing international safety guidelines and other standards such as OHSAS 18001, can highlight the strategic importance of OHS issues in a global context, as well as providing the opportunity to bring OHS actions closer to leadership positions, delivering a more socially responsible vision to company managers (Jones, 2017). Also, ISO 45001 focuses on involving OHS problems in the decision-making process within organizational management, bringing greater emphasis to the development and use of health and safety indicators as a way to demonstrate transparency and tangible meaning in the reports and data of the company (International Organization for Standardization, 2018; Jones, 2017).

\subsection{Performance indicators}

An organization's performance concerns the best way to achieve a certain objective, always related to economic, financial, quality, environment, and productivity issues, however, it is also possible to measure OHS performance (Kongsvik et al., 2010; Swuste et al., 2016).

Performance indicators are instruments that assist decision-making by helping to define strategic planning and the organization's strategy (Fischmann \& Zilber, 2000). They are measurable representations of an aspect of reality (Øien et al., 2011a). They reflect the situation of production processes and the work environment realistically (Swuste et al., 2016). They make it possible to understand what is intended to change and what is the current situation, helping to establish priorities and objectives, transforming them into goals to be followed; they evaluate the positive or negative side of an environment and the consequences of the activities applied in it (Almeida \& Nunes, 2014).

The use of this decision support tool can be observed in several sectors, from application in automotive battery industries (Oliveira et al., 2010), in a public hospital to evaluate the nursing service (Gabriel et al., 2011), in civil construction companies (Duarte et al., 2011), among others.

\subsubsection{Health and safety indicators}

The safety of a work environment is not easily described, measured, or controlled, its management must be carried out systematically, with constant monitoring of organizational performance through indicators (Reiman 
\& Pietikäinen, 2012). Indicators are data simplifications, while risks and their influence on organizations are complex (Kongsvik et al., 2010; li et al., 2015).

When the use of indicators is part of the OHS management system, managers and workers begin to evaluate prevention and diagnosis actions, acquiring more proactive and less reactive conduct (Almeida \& Nunes, 2014). The use of occupational safety indicators is inevitable for an appropriate OHS management - it is only possible to manage what you measure and control - and it must be carried out systematically so that changes and deviations during activities are perceived, benefiting in the evaluation of the effectiveness of the OHS program in the company, helping to understand the successes and failures and in the identification of critical areas and necessary actions (Louvar, 2010; Duarte et al., 2011; Reiman \& Pietikäinen, 2012).

Duarte et al. (2011) define some steps to be followed in the process of implementing a system of OHS indicators in an organization. The process consists of three stages: the collection, processing, and analysis of data, in which the collection of information from the indicators must be analyzed systematically, understanding the relation between cause and effect that generated that result, and finally, it must be distributed in an understandable way to all involved in the process.

Hopkins (2007) discussed some differences between security indicators found. According to him, there are two dimensions of indicators: (i) personal security and (ii) process security. The first refers to accidents and problems directly linked to the worker, such as falls, trips, electric shocks, car accidents, etc. On the other hand, safety in the process concerns the performance of the activity, such as leakage of toxins or flammable materials capable of causing fire or explosions. A company cannot base its ability to manage OHS using statistical data on injuries or fatalities, it must also develop indicators that measure the dangers related to the process (Hopkins, 2007).

The selection of safety indicators is carried out by identifying essential factors to the management, in a way that the most relevant for the company are selected (Duarte et al., 2011; Almeida \& Nunes, 2014). Safety indicators must be quantifiable, easy to understand, unambiguous, reliable, stable, sensitive to changes, economically viable, and significant (Øien et al., 2011b; Swuste et al., 2016).

It is common to have a division between reactive and proactive indicators, the former being related to measurements after accidents, while the latter concerns measurements of factors that contribute to accidents (Øien et al., 2011b). However, only reactive indicators are not enough, since accidents may not happen in a workplace but there is still risk exposure to the worker, therefore, the use of reactive indicators combined with proactive indicators are the best option (Øien et al., 2011b; Pasman \& Rogers, 2014; Podgórski, 2015; Sinelnikov et al., 2015; Mohammadfam et al., 2017).

According to Swuste et al. (2016), the formulation of indicators is not an easy process, normally carried out through studies in literature and, often, based on organizational experiences and common sense. They are usually developed based on what is found in current legislation and international standards. It is possible to base indicators that serve to maintain control of security activities in an organization through information in Regulatory Standards and also in what the OHSAS dictates.

The quantity and demand for safety indicators varies and depends on the company's situation, however, if too much emphasis is placed on certain indicators, other problems can be overlooked and neglected. So, it is clear the need of choosing the most appropriate indicators, once that managers' attention is a limited resource that must be optimized (Harms-Ringdahl, 2009; Kongsvik et al., 2010). One of the ways to carry out this evaluation and selection of indicators is through the application of multicriteria methods since they consider all the factors involved simultaneously (Dağdeviren \& Yüksel, 2008).

\subsection{FAHP method}

In decision-making scenarios consisting of conflicting objectives and criteria, it is possible to use well-known mathematical tools to assess the various parameters and find an optimal result, these are called multicriteria decision-making methods (Kumar et al., 2017; Briozo \& Musetti, 2015). These methods have been successfully applied in different fields of knowledge, such as in cases of the selection of an emergency care unit location (Briozo \& Musetti, 2015), selection of commercial land (Brandalise et al., 2019), in the selection and evaluation of suppliers (Ho et al., 2010), and also used for the selection of performance indicators (Infante et al., 2017; Kumar et al., 2017). Among the known methods can be mentioned the Analytic Hierarchy Process - AHP, the TOPSIS (Technique for Order of Preference by Similarity to ldeal Solution), the multi-attribute utility theory method (MAUT), among others (Kumar et al., 2017; Wollmann et al., 2014).

The Fuzzy AHP (FAHP) method is a variation of the traditional AHP method that uses fuzzy numbers to perform a pairwise comparison of criteria (Fígaro Ulhoa et al., 2017). Fuzzy numbers have an imprecise and 
inaccurate value, aim to express linguistic variables properly, helping to represent the problem in a more realistic way (Dağdeviren \& Yüksel, 2008; Zheng et al., 2012).

The preference in using the AHP method comes from its relative ease in dealing with multiple criteria, facilitating the understanding; however, this method does not reflect the human way of thinking (Kahraman et al., 2003; Janackovic et al., 2013). This method has a hierarchical structure composed of the general objective at the top, followed by the criteria that will evaluate the alternatives and, finally, the alternatives. However, the AHP does not deal with the inaccuracies and ambiguities so present in decision-making processes, which weakens its use, allowing the use of other methods in its place or combined with it, as is the case with fuzzy logic (Linhares et al., 2012).

The fuzzy logic processes information from linguistic variables and, for humans, the evaluation using numerical values is more complicated and inaccurate, therefore, the use of this logic becomes more precise (Silva et al., 2017). The combination of the AHP method with the fuzzy logic allows the solution of hierarchy problems and fuzzy problems while bringing the benefit of incorporating intangible judgments using expressions in natural languages and making the evaluation more humanized (Dağdeviren \& Yüksel, 2008; Abdullah, 2013; Mardani et al., 2015).

Therefore, the preference of using the FAHP method in this study is justified because of its ability to handle uncertainties in the decision process and still being able to achieve the best alternative, as well as its success at previous studies of prioritizing indicators and more specifically OHS indicators (Bozbura et al., 2007; Govindan et al., 2017; Janackovic et al. 2013; Adem et al., 2020).

The application of the FAHP method consists of:

a) Define the decision hierarchy, identifying the objective of the decision, the criteria and the alternatives;

b) Define the set of linguistic terms that will be used on the scale to make comparisons between the alternatives, also, the fuzzy number and the fuzzy value corresponding to each term, shown in Table 1, are defined. The fuzzy numbers used here are triangular. According to Chang (1996), a triangular fuzzy number $M_{l}$ can be denoted by $(I, m, u)$, where $l$ stands for the lower value, $m$ the modal value and $u$ the upper value;

Table 1. Scale of judgment.

\begin{tabular}{cccc}
\hline ID & DESCRIPTION & FUZZY NUMBER & FUZZY VALUE \\
\hline El & Equal Importance & $\left(l_{e p}, m_{e p}, u_{e}\right)$ & $(1,1,3)$ \\
Ml & Moderate Importance & $\left(l_{m p}, m_{m p}, u_{m i}\right)$ & $(1,3,5)$ \\
S1 & Strong Importance & $\left(l_{s p}, m_{s p}, u_{s i}\right)$ & $(3,5,7)$ \\
VSI & Very Strong Importance & $\left(l_{v s ?}, m_{v s}, u_{v s}\right)$ & $(5,7,9)$ \\
Al & Absolute Importance & $\left(l_{a p}, m_{a p}, u_{a p}\right)$ & $(7,9,9)$ \\
\hline
\end{tabular}

Source: Adapted from Dağdeviren \& Yüksel (2008) and Janackovic et al. (2013).

c) Pair-wise comparison of the criteria concerning the objective and then a pair-wise comparison of the evaluations concerning the criteria. These comparisons produce a square matrix of fuzzy numbers where the element $a_{j i}$ is equal to $1 / a_{i j}$. Since the elements of this matrix are fuzzy numbers, the Equation 1 shows how to obtain this value, according to Chang (1996);

$$
\left(l_{i}, m_{i}, u_{i}\right)^{-1}=\left(\frac{1}{u_{i}}, \frac{1}{m_{i}}, \frac{1}{l_{i}}\right)
$$

d) According to Lima Junior (2013), FAHP consists of two iterations, the first one defines the weight of the criteria, therefore, for each criteria $i$, a measurement of preference $M_{i}^{j}$ should be obtained concerning the decision goal $j$, where $M$ is a triangular fuzzy number. And the second iteration is the evaluation of the alternatives. For each alternative $i$ and each specialist $k$, a measurement of preference $M_{i k}^{j}$ should be obtained in relation to the criteria $j$.

Equation 2 shows how to obtain the measurements of $M_{i}^{j}$, where $k$ refers to the respondents and the equation represents an arithmetic mean.

$$
M_{i}^{j}=\frac{1}{k}\left[M_{i l}^{j}+\ldots+M_{i k}^{j}\right]
$$

Therefore, the synthetic average $S_{i}$ is calculated for each of the objects according to Equation 3, which is composed of the multiplication of two sections. The first section is the sum of the note given to an object 
when compared to all others and the second section is the sum of all the notes of all the objects evaluated when compared to the others.

$$
S_{i}=\sum_{j=1}^{m} M_{i}^{j} \otimes\left[\sum_{i=1}^{n} \sum_{j=1}^{m} M_{i}^{j}\right]^{-1}
$$

e) With the synthetic measure of each of the objects to be evaluated by the FAHP, the preference value is calculated, which represents how much each of them is preferable in relation to the other. For example, comparing two objects $i=1$ and $i=2$, we have:

$$
\begin{gathered}
S_{l}=\left(l_{l}, m_{1}, u_{l}\right) \geq S_{2}=\left(l_{2}, m_{2}, u_{2}\right) \\
V\left(S_{I} \geq S_{2}\right)=\mu_{M_{l}}(d)
\end{gathered}
$$

in which:

$$
\mu_{M_{l}}(d)=\left\{\begin{array}{c} 
\\
1, \text { if } m_{1} \geq m_{2} \\
0, \text { if } l_{2} \geq u_{1} \\
\frac{l_{2}-u_{1}}{\left(m_{l}-u_{1}\right)-\left(m_{2}-l_{2}\right)}, \text { otherwise }
\end{array}\right\}
$$

f) Once the preference values of each of the objects evaluated are obtained over the others, it is necessary to find the global preference $\left(d^{\prime}\left(A_{i}\right)\right)$ value of the objects. This value is found by Equation 7:

$$
d\left(A_{i}\right)=\operatorname{MIN} V\left(S_{i} \geq S_{k}\right) \text { for } k=1.2, \ldots, n ; k \neq i
$$

That is, the global preference value of each object is the minimum preference value obtained from comparisons between this object and the others.

g) Determine the weights of objects by normalizing their global preference values. With weights, it is possible to define which are the most priority in relation to the others.

\section{Research method}

The study is classified as quantitative and exploratory research that sought to list OHS indicators and examine their level of importance in companies and how is the priority relationship between them through the application of a multicriteria method collecting the opinion of some entrepreneurs.

The decision hierarchy for the FAHP is defined with the general objective, followed by the criteria and alternatives. The objective is to define the priority order of categories of OHS indicators for organizations. For the research application, no criteria were used to make the comparison between the alternatives, the assessment is at the discretion of the questionnaire respondent. The alternatives are the categories of indicators; therefore, a literature review was carried out for the collection of the most relevant OHS indicators. The hierarchical order of application of the FAHP method, in this case, is given by the objective followed by the categories of OHS indicators.

Once the decision hierarchy was defined, a questionnaire was developed for entrepreneurs to compare and evaluate the categories of OHS indicators. From the information collected, a tabulation of the results and the FAHP calculations were made, identifying the most relevant category according to the companies' opinion.

Initially, a collection of the main OHS indicators presented in the literature was carried out. Based on similar characteristics between the indicators, they were grouped into eight categories. Then, the FAHP was structured. An assessment scale composed of linguistic variables was defined and questionnaires for data collection were created. Answered questionnaires evaluating the alternatives were tabulated and calculated according to the FAHP methodology, the results were analyzed and it was possible to reach the conclusion of the order of priority among the objects evaluated. 


\section{Results}

This section is divided into two parts, the first concerns the systematization of OHS indicators found in the literature review and the second concerns the application of the fuzzy AHP method.

\subsection{OHS Indicators}

Through a literature review, it was identified several indicators used to measure the performance of an organization's OHS. After filtering and selecting the most relevant, it listed fifty-five indicators. They were grouped into eight categories: Accidents or Diseases, Risk Assessment, Protective Equipment, OHS Management, Prevention Measures, Employee Participation, Risks and Training.

The Accidents or Diseases category represents the indicators that account for and maintain control over information about undesirable events in the workplace, such as accidents, illnesses, near accidents, and incidents. The Risk Assessment category investigates risk assessment actions, such as safety studies and preliminary assessments. Protective Equipment category is related to personal and collective protective equipment. OHS Management category is about actions of OHS management, such as the allocation of financial resources, the number of meetings to address issues.

The Prevention Measures category relates to actions focused on accident prevention, such as the number of inspections and the number of preventive actions completed. The Employee Participation category measures employee participation in OHS-related decision-making, participation in OHS meetings, and the number of employees who are aware of safety measures.

The Risks category is related to the number of risks identified, the hazard index, etc. The last category is Training, which monitors training related to OHS actions in the company. The systematization facilitates the evaluation of the indicators since the most similar ones can be compared with each other.

\subsection{Application of FAHP}

The FAHP application process consists of four stages: definition of the decision hierarchy, definition of linguistic variables, evaluation of objects, and collection of results (Chang, 1996; Janackovic et al., 2013; Lima Junior, 2013). The applications of these four steps are described in the following sections.

\subsubsection{Decision hierarchy}

The decision hierarchy is composed of the objective, followed by alternatives. The objective was to identify priority OHS indicators from the companies' point of view and the alternatives were the indicator categories, listed in Table 2.

The identifiers were defined to facilitate the reading and understanding of future steps as calculations.

Table 2. List of categories.

\begin{tabular}{cc}
\hline IDENTIFIER & INDICATOR CATEGORY \\
\hline C1 & Accidents or Diseases \\
C2 & Risk Assessment \\
C3 & Protective Equipment \\
C4 & OHS Management \\
C5 & Prevention Measures \\
C6 & Employee Participation \\
C7 & Risks \\
C8 & Training \\
\hline
\end{tabular}

Source: Authors (2020).

\subsubsection{Linguistic variable}

The scale presented in Table 3 was defined to facilitate the collection of the respondent's perception of priority of the indicators and to minimize possible errors of understanding, based on the scales presented by Dağdeviren \& Yüksel (2008) and Janackovic et al. (2013).

This scale was used in questionnaires sent to companies. 
Table 3. Linguistic scale of the judgments.

\begin{tabular}{cc}
\hline IDENTIFIER & DESCRIPTION \\
\hline El & Equal importance \\
MI & A is of moderate importance over B \\
Sl & A is of strong importance over B \\
VSI & A is of very strong importance over B \\
Al & A is of absolute importance over B \\
\hline
\end{tabular}

Source: Adapted from Dağdeviren \& Yüksel (2008) and Janackovic et al. (2013).

\subsubsection{Evaluation of indicator categories}

Once the scale was defined, worksheets for the pairwise comparison were prepared, Chart 1 shows an example of a blank worksheet.

Chart 1. Comparison between category $\mathrm{C} 1$ and the others.

\begin{tabular}{|c|c|c|c|c|c|c|c|c|c|c|}
\hline Category & $\mathrm{Al}$ & $\mathrm{VSI}$ & $\mathrm{SI}$ & $\mathrm{Ml}$ & $\mathrm{El}$ & $1 / \mathrm{MI}$ & $1 / \mathrm{SI}$ & $1 / \mathrm{VSI}$ & $1 / \mathrm{Al}$ & Category \\
\hline Accidents or Diseases & & & & & & & & & & Risk Assessment \\
\hline Accidents or Diseases & & & & & & & & & & Protective Equipment \\
\hline Accidents or Diseases & & & & & & & & & & OHS Management \\
\hline Accidents or Diseases & & & & & & & & & & Prevention Measures \\
\hline Accidents or Diseases & & & & & & & & & & Employee Participation \\
\hline Accidents or Diseases & & & & & & & & & & Risks \\
\hline Accidents or Diseases & & & & & & & & & & Training \\
\hline
\end{tabular}

Source: Authors (2020).

Based on this definition, online questionnaires were sent to about forty-three companies from different segments obtained through a company database.

\subsubsection{Application results}

Once the questionnaires were sent, the next step was to analyze the responses and start the FAHP calculations. More than forty companies were reached but only six answered the questionnaire, however, four of the responses were invalid and had to be discarded, leaving only two responses within the conformities to be used. Each answer marked in the spreadsheet has a set of corresponding numbers, the fuzzy numbers, as already defined in Table 1 . These fuzzy values can be represented according to Tables 4 and 5 , respectively representing each of the responses of the study participants. In these tables, there are matrices of order eight in which the diagonals are composed of the set of numbers $(1,1,1)$. The values below the diagonal are obtained by Equation 1 .

Table 4 - Matrix of judgments by the first respondent

\begin{tabular}{ccccccccc}
\hline & $\mathrm{C} 1$ & $\mathrm{C} 2$ & $\mathrm{C} 3$ & $\mathrm{C} 4$ & $\mathrm{C} 5$ & $\mathrm{C} 6$ & $\mathrm{C} 7$ & $\mathrm{C} 8$ \\
\hline $\mathrm{C} 1$ & $(1,1,1)$ & $(7,9,9)$ & $(5,7,9)$ & $(0.2,0.3,1)$ & $(7,9,9)$ & $(0.2,0.3,1)$ & $(0.2,0.3,1)$ & $(0.2,0.3,1)$ \\
$\mathrm{C} 2$ & $(0.1,0.1,0.1)$ & $(1,1,1)$ & $(7,9,9)$ & $(7,9,9)$ & $(7,9,9)$ & $(0.2,0.3,1)$ & $(0.2,0.3,1)$ & $(0.2,0.3,1)$ \\
C3 & $(0.1,0.1,0.2)$ & $(0.1,0.1,0.1)$ & $(1,1,1)$ & $(0.1,0.1,0.1)$ & $(0.1,0.1,0.1)$ & $(1,1,3)$ & $(0.1,0.1,0.1)$ & $(1,1,3)$ \\
C4 & $(1,3,5)$ & $(0.1,0.1,0.1)$ & $(7,9,9)$ & $(1,1,1)$ & $(7,9,9)$ & $(7,9,9)$ & $(7,9,9)$ & $(7,9,9)$ \\
C5 & $(0.1,0.1,0.1)$ & $(0.1,0.1,0.1)$ & $(7,9,9)$ & $(0.1,0.1,0.1)$ & $(1,1,1)$ & $(1,1,3)$ & $(0.2,0.3,1)$ & $(1,1,3)$ \\
C6 & $(1,3,5)$ & $(1,3,5)$ & $(0.3,1,1)$ & $(0.1,0.1,0.1)$ & $(0.3,1,1)$ & $(1,1,1)$ & $(1,1,3)$ & $(1,1,3)$ \\
C7 & $(1,3,5)$ & $(1,3,5)$ & $(7,9,9)$ & $(0.1,0.1,0.1)$ & $(1,3,5)$ & $(0.3,1,1)$ & $(1,1,1)$ & $(1,1,3)$ \\
C8 & $(1,3,5)$ & $(1,3,5)$ & $(0.3,1,1)$ & $(0.1,0.1,0.1)$ & $(0.3,1,1)$ & $(0.3,1,1)$ & $(0.3,1,1)$ & $(1,1,1)$ \\
\hline
\end{tabular}

Table 5. Matrix of judgments by the second respondent.

\begin{tabular}{|c|c|c|c|c|c|c|c|c|}
\hline & C1 & C2 & C3 & C4 & C5 & C6 & C7 & C8 \\
\hline $\mathrm{C} 1$ & $(1,1,1)$ & $(0.1,0.1,0.1)$ & $(1,3,5)$ & $(0.1,0.1,0.1)$ & $(1,3,5)$ & $(0.1,0.1,0.1)$ & $(1,1,3)$ & $(0.1,0.2,0.3)$ \\
\hline $\mathrm{C} 2$ & $(7,9,9)$ & $(1,1,1)$ & $(7,9,9)$ & $(0.1,0.2,0.3)$ & $(1,1,3)$ & $(0.2,0.3,1)$ & $(5,7,9)$ & $(0.2,0.3,1)$ \\
\hline $\mathrm{C} 3$ & $(0.2,0.3,1)$ & $(0.1,0.1,0.1)$ & $(1,1,1)$ & $(0.1,0.1,0.1)$ & $(1,1,3)$ & $(1,1,3)$ & $(1,1,3)$ & $(0.1,0.2,0.3)$ \\
\hline C4 & $(7,9,9)$ & $(3,5,7)$ & $(7,9,9)$ & $(1,1,1)$ & $(0.1,0.1,0.1)$ & $(0.1,0.1,0.1)$ & $(7,9,9)$ & $(1,1,3)$ \\
\hline C5 & $(0.2,0.3,1)$ & $(0.3,1,1)$ & $(0.3,1,1)$ & $(7,9,9)$ & $(1,1,1)$ & $(0.1,0.1,0.1)$ & $(1,1,3)$ & $(1,1,3)$ \\
\hline C6 & $(7,9,9)$ & $(1,3,5)$ & $(0.3,1,1)$ & $(7,9,9)$ & $(7,9,9)$ & $(1,1,1)$ & $(0.1,0.1,0.2)$ & $(0.1,0.2,0.3)$ \\
\hline C7 & $(0.3,1,1)$ & $(0.1,0.1,0.2)$ & $(0.3,1,1)$ & $(0.1,0.1,0.1)$ & $(0.3,1,1)$ & $(5,7,9)$ & $(1,1,1)$ & $(0.1,0.2,0.3)$ \\
\hline C8 & $(3,5,7)$ & $(1,3,5)$ & $(3,5,7)$ & $(0.3,1,1)$ & $(0.3,1,1)$ & $(3,5,7)$ & $(3,5,7)$ & $(1,1,1)$ \\
\hline
\end{tabular}


Following Chang's methodology (1996), the next step was the construction of the matrix aggregating the two responses, in which the values are the average of the responses, as can be seen in Table 6 .

Table 6. Average of responses.

\begin{tabular}{ccccccccc}
\hline & C1 & C2 & C3 & C4 & C5 & C6 & C7 & C8 \\
\hline C1 & $(1,1,1)$ & $(3.56,4.56,4.57)$ & $(3,5,7)$ & $(0.16,0.22,0.57)$ & $(4,6,7)$ & $(0.16,0.22,0.57)$ & $(0.6,0.67,2)$ & $(0.17,0.27,0.67)$ \\
C2 & $(0.22,0.22,0.28)$ & $(1,1,1)$ & $(7,9,9)$ & $(3.57,4,6,4,67)$ & $(4,5,6)$ & $(0.2,0.33,1)$ & $(2.6,3,67,5)$ & $(0.2,0.33,1)$ \\
C3 & $(0.14,0.2,0.33)$ & $(0.11,0.11,0.14)$ & $(1,1,1)$ & $(0.11,0.11,0.14)$ & $(0.56,0.56,1.57)$ & $(1,1,3)$ & $(0.56,0.56,1.57)$ & $(0.57,0.6,1.67)$ \\
C4 & $(1.75,4.5,6.43)$ & $(0.21,0.22,0.28)$ & $(7,9,9)$ & $(1,1,1)$ & $(3.56,4.56,4.57)$ & $(3.56,4.56,4.57)$ & $(7,9,9)$ & $(4,5,6)$ \\
C5 & $(0.14,0.17,0.25)$ & $(0.17,0.2,0.25)$ & $(0.64,1.8,1.8)$ & $(0.22,0.22,0.28)$ & $(1,1,1)$ & $(0.56,0.56,1.57)$ & $(0.6,0.67,2)$ & $(1,1,3)$ \\
C6 & $(1.75,4.5,6.43)$ & $(1,3,1)$ & $(0.33,1,1)$ & $(0.22,0.22,0.28)$ & $(0.64,1.8,1.8)$ & $(1,1,1)$ & $(0.56,0.56,1.57)$ & $(0.57,0.6,1.67)$ \\
C7 & $(0.5,1.5,1.67)$ & $(0.2,0.27,0.38)$ & $(0.64,1.8,1.8)$ & $(0.11,0.11,0.14)$ & $(0.5,1.5,1.67)$ & $(0.63,1.75,1.8)$ & $(1,1,1)$ & $(0.57,0.6,1.67)$ \\
C8 & $(1.5,3.75,5.83)$ & $(1,3,5)$ & $(0.6,1.67,1.75)$ & $(0.17,0.2,0.25)$ & $(0.33,1,1)$ & $(0.6,1.67,1.75)$ & $(0.6,1.67,1.75)$ & $(1,1,1)$ \\
\hline
\end{tabular}

Source: Authors (2020).

These average values are important to calculate the synthetic measures that were used to define priorities among the alternatives evaluated. The synthetic measures are calculated using Equation 3; therefore, eight values are corresponding to each of the categories of indicators, indicated by Equations 8 to 15 .

$$
\begin{aligned}
& S_{C 1}=(12.64,17.93,23.38) \otimes\left(\frac{1}{154.99}, \frac{1}{124.83}, \frac{1}{83.88}\right)=(0.08,0.14,0.28) \\
& S_{C 2}=(18.79,24.15,27.95) \otimes\left(\frac{1}{154.99}, \frac{1}{124.83}, \frac{1}{83.88}\right)=(0.12,0.19,0.33) \\
& S_{C 3}=(4.05,4.13,9.43) \otimes\left(\frac{1}{154.99}, \frac{1}{124.83}, \frac{1}{83.88}\right)=(0.03,0.03,0.11) \\
& S_{C 4}=(28.07,37.83,40.85) \otimes\left(\frac{1}{154.99}, \frac{1}{124.83}, \frac{1}{83.88}\right)=(0.18,0.3,0.49) \\
& S_{C 5}=(4.32,5.61,10.15) \otimes\left(\frac{1}{154.99}, \frac{1}{124.83}, \frac{1}{83.88}\right)=(0.03,0.04,0.12) \\
& S_{C 6}=(6.06,12.69,14.78) \otimes\left(\frac{1}{154.99}, \frac{1}{124.83}, \frac{1}{83.88}\right)=(0.04,0.1,0.18) \\
& S_{C 8}=(5.8,13.95,18.33) \otimes\left(\frac{1}{154.99}, \frac{1}{124.83}, \frac{1}{83.88}\right)=(0.04,0.11,0.22) \\
& S_{C 7}=(4.14,8.53,10.13) \otimes\left(\frac{1}{154.99}, \frac{1}{124.83}, \frac{1}{83.88}\right)=(0.03,0.07,0.12) \\
& \text { (1) }
\end{aligned}
$$

These measures were then compared with each other using Equations 5 and 6, resulting in preference values for each of the categories over the others. Equations 16 to 22 demonstrate the comparison between category C1: Accidents or Diseases with the other categories and the respective preference values between the categories.

$$
\begin{gathered}
V\left(S_{C 1} \geq S_{C 2}\right)=\frac{l_{2}-u_{1}}{\left(m_{1}-u_{1}\right)-\left(m_{2}-l_{2}\right)}=\frac{0.12-0.28}{(0.14-0.28)-(0.19-0.12)}=1.092 \\
V\left(S_{C 1} \geq S_{C 3}\right)=m_{1} \geq m_{3}=1 \\
V\left(S_{C l} \geq S_{C 4}\right)=\frac{l_{4}-u_{1}}{\left(m_{1}-u_{1}\right)-\left(m_{4}-l_{4}\right)}=\frac{0.18-0.28}{(0.14-0.28)-(0.3-0.18)}=0.597 \\
V\left(S_{C 1} \geq S_{C 5}\right)=m_{1} \geq m_{5}=1
\end{gathered}
$$




$$
\begin{aligned}
& V\left(S_{C l} \geq S_{C 6}\right)=m_{1} \geq m_{6}=1 \\
& V\left(S_{C l} \geq S_{C 7}\right)=m_{1} \geq m_{7}=1 \\
& V\left(S_{C l} \geq S_{C 8}\right)=m_{1} \geq m_{8}=1
\end{aligned}
$$

For example, when comparing categories $\mathrm{C} 1$ and $\mathrm{C} 2$, there is a preference value of 1.09 , while between categories $\mathrm{C} 1$ and $\mathrm{C} 8$ the value is 1 . Finding these preference values for all categories makes it possible to find the weight of each category and, consequently, identify the order of priority according to the companies' evaluation. The preference values for comparisons between all categories can be seen in Table 7 .

Table 7. Preference values.

\begin{tabular}{ccccccccc}
\hline & $\boldsymbol{S}_{\boldsymbol{C} 1}$ & $\boldsymbol{S}_{\boldsymbol{C} 2}$ & $\boldsymbol{S}_{\boldsymbol{C} 3}$ & $\boldsymbol{S}_{\boldsymbol{C} 4}$ & $\boldsymbol{S}_{\boldsymbol{C} 5}$ & $\boldsymbol{S}_{\boldsymbol{C} 6}$ & $\boldsymbol{S}_{\boldsymbol{C} 7}$ & $\boldsymbol{S}_{\boldsymbol{C} 7}$ \\
\hline $\boldsymbol{S}_{\boldsymbol{C} 1}$ & - & 1.092 & 1 & 0.597 & 1 & 1 & 1 & 1 \\
$\boldsymbol{S}_{\boldsymbol{C} 2}$ & 1 & - & 1 & 0.579 & 1 & 1 & 1 & 1 \\
$\boldsymbol{S}_{\boldsymbol{C} 3}$ & 0.216 & 0 & - & 0 & 0.877 & 0.515 & 0.706 & 0.486 \\
$\boldsymbol{S}_{\boldsymbol{C} 4}$ & 1 & 1 & 1 & - & 1 & 1 & 1 & 1 \\
$\boldsymbol{S}_{\boldsymbol{C} 5}$ & 0.283 & 0 & 1 & 0 & - & 0.589 & 0.799 & 0.554 \\
$\boldsymbol{S}_{\boldsymbol{C} 6}$ & 0.691 & 0.372 & 1 & 0 & 1 & - & 1 & 0.932 \\
$\boldsymbol{S}_{\boldsymbol{C} 7}$ & 0.333 & 0 & 1 & 0 & 1 & 0.706 & - & 0.653 \\
$\boldsymbol{S}_{\boldsymbol{C} 8}$ & 1.228 & 0.834 & 1 & 0.204 & 1 & 1 & 1 & - \\
\hline
\end{tabular}

Source: Authors (2020).

The next step is to calculate the global preference value for each of the objects, using Equation 7. Equation 23 presents the formula applied to category $\mathrm{C} 1$, it seeks to identify the minimum value obtained from the comparisons with the other categories, the values shown in Table 7.

$$
d\left(C_{1}\right)=\operatorname{MINV}\left(S_{C 1} \geq S_{C 2}, S_{C l} \geq S_{C 3}, S_{C l} \geq S_{C 4}, S_{C 1} \geq S_{C 5}, S_{C l} \geq S_{C 6}, S_{C l} \geq S_{C 7}, S_{C l} \geq S_{C 8}\right)
$$

From Equation 24 to Equation 31, there's the formula applied to the values of each of the categories.

$$
\begin{gathered}
d\left(C_{1}\right)=\operatorname{MIN}(1.09,1,0.59,1,1,1,1)=0.59 \\
d\left(C_{2}\right)=\operatorname{MIN}(1,1,0.58,1,1,1,1)=0.58 \\
d\left(C_{3}\right)=\operatorname{MIN}(0.22,0,0,0.88,0.52,0.71,0.49)=0 \\
d\left(C_{4}\right)=\operatorname{MIN}(1,1,1,1,1,1,1)=1 \\
d\left(C_{5}\right)=\operatorname{MIN}(0.28,0,1,0,0.59,0.8,0.55)=0 \\
d\left(C_{6}\right)=\operatorname{MIN}(0.69,0.37,1,0,1,1,0.93)=0 \\
d\left(C_{7}\right)=\operatorname{MIN}(0.33,0,1,0,1,0.71,0.65)=0 \\
d\left(C_{8}\right)=\operatorname{MIN}(1.23,0.83,1,0.2,1,1,1)=0.20
\end{gathered}
$$

Once the global preference values for each of the categories have been calculated, they can then be normalized to find the weight of each category and, consequently, which has the highest priority over the others. These values can be viewed in Table 8 . 


\begin{tabular}{ccc}
\hline CATEGORY & GLOBAL PREFERENCE & STANDARD WEIGHT \\
\hline C1 - Accidents and Diseases & 0.59 & 0.25 \\
C2 - Risk assessment & 0.58 & 0.24 \\
C3 - Protective Equipment & 0 & 0 \\
C4 - OHS Management & 1 & 0.42 \\
C5 - Prevention Measures & 0 & 0 \\
C6 - Employee Participation & 0 & 0 \\
C7 - Risks & 0 & 0 \\
C8 - Training & 0.20 & 0.09 \\
\hline
\end{tabular}

Source: Authors (2020).

Thus, the order of preference demonstrated by the respondents for the indicators categories is: $\mathrm{C} 4>\mathrm{C} 1>$ $\mathrm{C} 2>\mathrm{C} 8>\mathrm{C} 3=\mathrm{C} 5=\mathrm{C} 6=\mathrm{C} 7$. The categories $\mathrm{C} 3, \mathrm{C} 5, \mathrm{C} 6$, and $\mathrm{C} 7$ have the same value of preference therefore for all were attributed a value of zero. Linhares et al. (2012) argue that this can happen due to the evaluations having many answers in the extremities of the preference degrees. Or it can also be a characteristic of the used method since it determines the weight using the minimum value between the comparisons and since there is a reasonable number of objects being compared, the possibility of the alternative weight values being zero increases.

\section{Final considerations}

The main objective of the study, namely to use the FAHP as a tool to rank the main OHS indicators according to their priority given by companies, was achieved. The research process for collecting indicators resulted in more than fifty indicators even after extensive filtering. This large number of indicators shows the importance of an adequate OHS management, able to effectively consider and choose the most appropriate indicators and prioritize the most critical. This research process also showed a lack of standardization of the indicators in the literature, some studies presented only the title of the indicators while others presented the equations. These differences hinder the understanding and application by companies. Therefore, the systematization of the found indicators into eight categories in this article was done as a way of formalization of the findings, aggregating similar attributes focusing on the field of application of the indicators, in order to ease the understanding.

The use of the FAHP method was satisfactory for the study, achieving a very clear result based on the respondents' perspective. The category of indicators OHS Management was considered the most important when compared to the others and should be prioritized. This result is similar to Janackovic et al. (2013) that found that the organizational factors category is the most relevant, which means that indicators about management efficiency and workplace safety control are the most important ones. The second category was Accidents and Diseases, followed by Risk Assessment and then Trainings, the other categories were tied for last. Despite reaching a satisfactory result, it is worth mentioning that this priority hierarchy was defined according to the respondents' experiences and, therefore, could change if there were different or even more respondent companies.

It is worth to discuss the collection of the companies' opinion. In this study, questionnaires were sent to more than forty companies that could choose to participate in the research. Six companies responded, four of them answered incorrectly and were discarded, resulting in only two answers for the study. The small number of participants may influence the results and act as a limitation to the study, however, the fact that the companies choose to participate voluntarily in the research is a way of validating the population of the research, as said by El-Attar \& Miller (2009).

For future works it is suggested to replicate the study in order to increase the number of participants and extend the application of the FAHP to not only the categories of the indicators but also the indicators themselves, identifying the most relevant among its category and among them all. Another suggestion is to apply the questionnaire to different types of industry and compare the results, identifying if the perception of relevance for these categories of indicators change according to the field of the respondents.

\section{References}

Abdullah, L. (2013). Fuzzy multi criteria decision making and its applications: a brief review of category. Procedia: Social and Behavioral Sciences, 97, 131-136. http://dx.doi.org/10.1016/j.sbspro.2013.10.213.

Adem, A., Çakit, E., \& Dağdeviren, M. (2020). Occupational health and safety risk assessment in the domain of Industry 4.0. SN Applied Sciences, 2(5), 1-6. http://dx.doi.org/10.1007/s42452-020-2817-x.

Alli, B. 0. (2008). Fundamental Principles of Occupational Health and Safety (Vol. 1). Geneva: International Labour Office. 
Almeida, C. L., \& Nunes, A. B. de A. (2014). Proposta de indicadores para avaliação de desempenho dos Sistemas de Gestão Ambiental e de Segurança e Saúde no Trabalho de Empresas do ramo de engenharia consultiva. Gestão \& Produção, 21(4), 810-820. http:// dx.doi.org/10.1590/0104-530X649.

Barbosa, C., Azevedo, R., \& Rodrigues, M. A. (2019). Occupational safety and health performance indicators in SMEs: A literature review. Work (Reading, Mass.), 64(2), 217-227. http://dx.doi.org/10.3233/WOR-192988. PMid:31524191.

Brandalise, N., Pereira, A. S. A., \& De Brito Mello, L. C. B. (2019). Aid application multicriteria the decision based on AHP method and Fuzzy Logic in commercial land selection. Gestão \& Produção, 26(3), e3243. http://dx.doi.org/10.1590/0104-530x3243-19.

Brasil. Ministério da Fazenda (2018). Anuário Estatístico da Previdência Social - 2018. Anuário Estatístico Da Previdência Social ISSN. Brasília.

Briozo, R. A., \& Musetti, M. A. (2015). Método multicritério de tomada de decisão: aplicação ao caso da localização espacial de uma Unidade de Pronto Atendimento - UPA 24h. Gestão \& Produção, 22(4), 805-819. http://dx.doi.org/10.1590/0104-530X975-13.

Bozbura, F. T., Beskese, A., \& Kahraman, C. (2007). Prioritization of human capital measurement indicators using fuzzy AHP. Expert Systems with Applications, 32(4), 1100-1112. http://dx.doi.org/10.1016/j.eswa.2006.02.006.

Chang, D. Y. (1996). Applications of the extent analysis method on fuzzy AHP. European Journal of Operational Research, 95(3), 649655. http://dx.doi.org/10.1016/0377-2217(95)00300-2.

Chaves, S. C. L., Santana, V. S., Leão, l. C. M., Santana, J. N., \& Lacerda, L. M. A. A. (2009). Determinantes da implantação de um programa de segurança e saúde no trabalho. Revista Panamericana de Salud Pública, 25(3), 204-212. http://dx.doi.org/10.1590/ S1020-49892009000300003. PMid: 19454147.

Cobo, A., Vanti, A. A., \& Rocha, R. (2014). A fuzzy multicriteria approach for it governance evaluation. Journal of Information Systems and Technology Management, 11(2), 257-276. http://dx.doi.org/10.4301/S1807-17752014000200003.

Silva, E. H. D. R., Daniel, B. H., \& Oliveira, D. B. (2013). Os sistemas de gestão em segurança e saúde no trabalho em auxílio à prevenção de acidentes e doenças ocupacionais. Revista de Gestão Em Sistemas de Saúde, 1(02), 157-172. http://dx.doi.org/10.5585/rgss.v1i2.23.

Da $\square$ deviren, M., \& Yüksel, l. (2008). Developing a fuzzy analytic hierarchy process (AHP) model for behavior-based safety management. Information Sciences, 178(6), 1717-1733. http://dx.doi.org/10.1016/j.ins.2007.10.016.

Digital Observatory on Occupational Health and Safety (2018). Retrieved in 02 Abril 2019, from http://observatoriosst.mpt.mp.br

Duarte, C. M. de M., Rabbani, E. R. K., Junior, B. B., \& Jr, A. C. L. (2011). Gestão de segurança e saúde do trabalho em empresas construtoras através de sistema de indicadores. Revista de Ciências da Administração, 4, 1-20.

El-Attar, M. E., \& Miller, J. (2009). A subject-based empirical evaluation of SSUCD'sperformance in reducing inconsistencies in use case models. Empirical Software Engineering, 14(5), 477-512. http://dx.doi.org/10.1007/s10664-008-9101-9.

Fischmann, A. A., \& Zilber, M. A. (2000). Utilização de indicadores de desempenho para a tomada de decisões estratégicas: um sistema de controle. Revista de Administração Mackenzie, 1(1), 9-25.

Gabriel, C. S., Melo, M. R. C., Rocha, F. L. R., Bernardes, A., Miguelaci, T., \& Silva, M. L. P. (2011). Utilização de indicadores de desempenho em serviço de enfermagem de hospital público. Revista Latino-Americana de Enfermagem, 19(5), 1247-1254. http:// dx.doi.org/10.1590/S0104-11692011000500024. PMid:22030591.

Govindan, K., Mangla, S. K., \& Luthra, S. (2017). Prioritising indicators in improving supply chain performance using fuzzy AHP: insights from the case example of four Indian manufacturing companies. Production Planning and Control, 28(6-8), 552-573. http://dx.doi. org/10.1080/09537287.2017.1309716.

International Organization for Standardization (2018). Occupational Health and Safety Management Systems - Requirements with guidance for use (ISO 45001: 2018). Geneva: ISO

Harms-Ringdahl, L. (2009). Dimensions in safety indicators. Safety Science, 474), 481-482. http://dx.doi.org/10.1016/j.ssci.2008.07.019.

Ho, W., Xu, X., \& Dey, P. K. (2010). Multi-criteria decision making approaches for supplier evaluation and selection: A literature review. European Journal of Operational Research, 202(1), 16-24. http://dx.doi.org/10.1016/j.ejor.2009.05.009.

Hopkins, A. (2007). Thinking about process safety. Canberra, Australia: Faculty of Arts and National Research Centre for OHS Regulation Australian National University.

Hora, H. R. M., \& Costa, H. G. (2015). Proposta de um método multicritério para escolha múltipla. Production, 25(2), 441-453. http:// dx.doi.org/10.1590/0103-6513.084812.

Infante, R. P., De Oliveira, M. C., \& Assumpção, M. R. P. (2017). Uso de métodos multicritérios de tomada de decisão para seleção dos objetivos estratégicos e indicadores de performance considerados no Balanced Scorecard. Revista de Ciencia y Tecnología, 20(39), 45. http://dx.doi.org/10.15600/2238-1252/rct.v20n39p45-58.

Janackovic, G. L., Savic, S. M., \& Stankovic, M. S. (2013). Selection and ranking of occupational safety indicators based on fuzzy ahp: a case study in road construction companies. South African Journal of Industrial Engineering, 24(3), 175-189.

Jones, R. (2017). 1 S0 45001 and the Evolution of Occupational Health and Safety Management Systems. American Society of Safety Engineers, 1-9. Retrieved in 02 Abril 2019, from https://iso45001.assp.org/docs/10HS_Article_for_1SO_45001.pdf

Kahraman, C., Cebeci, U., \& Ulukan, Z. (2003). Multi-criteria supplier selection using fuzzy AHP. Logistics Information Management, 16(6), 382-394. http://dx.doi.org/10.1108/09576050310503367.

Kongsvik, T., Almklov, P., \& Fenstad, J. (2010). Organisational safety indicators: Some conceptual considerations and a supplementary qualitative approach. Safety Science, 48(10), 1402-1411. http://dx.doi.org/10.1016/j.ssci.2010.05.016.

Kumar, A., Sah, B., Singh, A. R., Deng, Y., He, X., Kumar, P., \& Bansal, R. C. (2017). A review of multi criteria decision making (MCDM) towards sustainable renewable energy development. Renewable and Sustainable Energy Reviews, 69, 596-609. https://doi. org/10.1016/j.rser.2016.11.191

Li, C., Chen, K., \& Xiang, X. (2015). An integrated framework for effective safety management evaluation: Application of an improved grey clustering measurement. Expert Systems with Applications, 42(13), 5541-5553. http://dx.doi.org/10.1016/j.eswa.2015.02.053. 
Lima Junior, F. R. (2013). Comparação entre os métodos Fuzzy TOPSIS e Fuzzy AHP no apoio à tomada de decisão para seleção de fornecedores (Dissertação de mestrado). Programa de Pós-graduação em Engenharia de Produção, Escola de Engenharia de São Carlos, Universidade de São Paulo, São Carlos. https://doi.org/10.11606/D.18.2013.tde-12092013-103003

Linhares, C. G., Gussen, C. T. G., \& Ribas, J. R. (2012 September 24-28). 0 método Fuzzy AHP aplicado à análise de riscos de usinas hidrelétricas em fase de construção. Congresso Latino-lberoamericano de Investigação Operacional (pp. 591-603). Rio de Janeiro: SOBRAPO.

Louvar, J. (2010). Guidance for Safety Performance Indicators. Process Safety Progress, 29(4), 387-388. http://dx.doi.org/10.1002/prs.10418.

Mardani, A., Jusoh, A., \& Zavadskas, E. K. (2015). Fuzzy multiple criteria decision-making techniques and applications - Two decades review from 1994 to 2014. Expert Systems with Applications, 42(8), 4126-4148. http://dx.doi.org/10.1016/j.eswa.2015.01.003.

Mohammadfam, 1., Kamalinia, M., Momeni, M., Golmohammadi, R., Hamidi, Y., \& Soltanian, A. (2017). Evaluation of the Quality of Occupational Health and Safety Management Systems Based on Key Performance Indicators in Certified Organizations. Safety and Health at Work, 8(2), 156-161. http://dx.doi.org/10.1016/j.shaw.2016.09.001. PMid:28593071.

Nordlöf, H., Wiitavaara, B., Högberg, H., \& Westerling, R. (2017). A cross-sectional study of factors influencing occupational health and safety management practices in companies. Safety Science, 95, 92-103. http://dx.doi.org/10.1016/j.ssci.2017.02.008.

Occupational Health and Safety Assessment Series. (2007). OHSAS 18001: Sistema de Gestão de Segurança e Saúde Ocupacional - requisitos.

Øien, K., Utne, 1. B., \& Herrera, l. A. (2011a). Building Safety indicators: Part 1 - Theoretical foundation. Safety Science, 49(2), $148-161$. http://dx.doi.org/10.1016/j.ssci.2010.05.012.

Øien, K., Utne, 1. B., Tinmannsvik, R. K., \& Massaiu, S. (2011b). Building Safety indicators: Part 2 - Application, practices and results. Safety Science, 49(2), 162-171. http://dx.doi.org/10.1016/j.ssci.2010.05.015.

Oliveira, O. J., Oliveira, A. B., \& Almeida, R. A. (2010). Gestão da segurança e saúde no trabalho em empresas produtoras de baterias automotivas: um estudo para identificar boas práticas. Production, 20(3), 481-490. http://dx.doi.org/10.1590/S0103-65132010005000029.

Oswald, D. (2020). Safety indicators: questioning the quantitative dominance. Construction Management and Economics, 38(1), 11-17. http://dx.doi.org/10.1080/01446193.2019.1605184.

Pasman, H., \& Rogers, W. (2014). How can we use the information provided by process safety performance indicators? Possibilities and limitations. Journal of Loss Prevention in the Process Industries, 30(1), 197-206. http://dx.doi.org/10.1016/j.jp.2013.06.001.

Podgórski, D. (2015). Measuring operational performance of OHS management system - A demonstration of AHP-based selection of leading key performance indicators. Safety Science, 73, 146-166. http://dx.doi.org/10.1016/j.ssci.2014.11.018.

Quelhas, 0., Alves, M., \& Filardo, P. (2014). As práticas da gestão da segurança em obras de pequeno porte: integração com os conceitos de sustentabilidade. Revista Produção Online, 4(2). http://dx.doi.org/10.14488/1676-1901.v4i2.309.

Reiman, T., \& Pietikäinen, E. (2012). Leading indicators of system safety - Monitoring and driving the organizational safety potential. Safety Science, 50(10), 1993-2000. http://dx.doi.org/10.1016/j.ssci.2011.07.015.

Sadoughi, S., Yarahmadi, R., Taghdisi, M. H., \& Mehrabi, Y. (2012). Evaluating and prioritizing of performance indicators of health, safety, and environment using fuzzy TOPSIS. 6(5), 2026-2033. https://doi.org/10.5897/AJBM11.1701

Silva, N. F., Vianna, C. M. M., Oliveira, F. S. G., Mosegui, G. B. G., \& Rodrigues, M. P. S. (2017). Fuzzy Visa: um modelo de lógica fuzzy para a avaliação de risco da Vigilância Sanitária para inspeção de resíduos de serviços de saúde. Physis (Rio de Janeiro, Brazil), 27(1), 127-146. http://dx.doi.org/10.1590/s0103-73312017000100007.

Sinelnikov, S., Inouye, J., \& Kerper, S. (2015). Using leading indicators to measure occupational health and safety performance. Safety Science, 72, 240-248. http://dx.doi.org/10.1016/j.ssci.2014.09.010.

Swuste, P., Theunissen, J., Schmitz, P., Reniers, G., \& Blokland, P. (2016). Process safety indicators, a review of literature. Journal of Loss Prevention in the Process Industries, 40, 162-173. http://dx.doi.org/10.1016/j.jlp.2015.12.020.

Fígaro Ulhoa, T., Henrique Palma Lima, R., \& Osiro, L (2017). Proposal of a method to identify and measure the relative importance of customer preferences based on fuzzy-AHP. Revista Gestão Da Produção Operações e Sistemas, 12(4), 153-178. http://dx.doi. org/10.15675/gepros.v12i3.1700.

Vassem, A. S., Fortunato, G., Bastos, S. A. P., \& Balassiano, M. (2017). Fatores constituintes da cultura de segurança: olhar sobre a indústria de mineração. Gestão \& Produção, 24(4), 719-730. http://dx.doi.org/10.1590/0104-530x1960-16.

Wachter, J. K., \& Yorio, P. L. (2014). A system of safety management practices and worker engagement for reducing and preventing accidents: An empirical and theoretical investigation. Accident; Analysis and Prevention, 68, 117-130. http://dx.doi.org/10.1016/j. aap.2013.07.029. PMid:23993683.

Wollmann, D., Maria, T. A. S., Vieira, G. E., \& Steiner, P. A. (2014). Details of the Analytic Hierarchy Process Technique for the Evaluation of Health Insurance Companies. Producao, 24(3), 583-593. http://dx.doi.org/10.1590/S0103-65132013005000070.

Zheng, G., Zhu, N., Tian, Z., Chen, Y., \& Sun, B. (2012). Application of a trapezoidal fuzzy AHP method for work safety evaluation and early warning rating of hot and humid environments. Safety Science, 50(2), 228-239. http://dx.doi.org/10.1016/j.ssci.2011.08.042. 